\title{
SURVEILLANCE MANAGEMENT FOR SECONDARY WATER COOLING QUALITY OF RSG GAS
}

\author{
Geni Rina Sunaryo \\ Pusat Teknologi dan Keselamatan Reaktor Nuklir, PTKRN - BATAN \\ Kawasan Puspiptek, Serpong, Tangerang Selatan, 15310 \\ E-mail: genirina@batan.go.id
}

Diterima: 25-01-2017

Diterima dalam bentuk revisi: 23-02-2017

Disetujui: 23-02-2017

\begin{abstract}
ABSTRAK
MANAJEMEN PENGAWASAN KUALITAS AIR PENDINGIN SEKUNDER DARI RSG GAS. Eksperimen pengawasan korosi baja karbon pipa pendingin sekunder RSG GAS dan identifikasi mikroba air pendingin sekunder RSG GAS telah dilakukan. Tujuan utamanya adalah memahami efektifitas pengelolaan air pendingin sekunder RSG GAS dengan adanya penambahan inhibitor dengan merek dagang tertentu dan biocide. Metode yang digunakan adalah menerapkan pengawasan korosi dan identifikasi pertumbuhan mikroba. Pengawasan korosi dilakukan dengan membuat rak kupon baja karbon dari pipa pendingin sekunder dalam bentuk rangkaian disc dan kemudian merendamnya di kolam penampung air kran dan menara air pendingin sekunder. Evaluasi hasil dilakukan secara visual setelah pencelupan selama empat bulan. Identifikasi pertumbuhan mikroba dilakukan dengan menggunakan tool kit yang sederhana prosedurnya hanya dengan pencelupan beberapa detik ke air sampel, tunggu selama 24 hingga 36 jam, dan kemudian bandingkan dengan referensi fabrikan untuk menentukan kisaran jumlah koloni yang ada per ml sampel. Dari hasil percobaan dipahami bahwa produk korosi baja karbon pipa pendingin sekunder lebih ditekan karena adanya penambahan inhibitor. Mikroba yang terdeteksi ada di dalam kolam menara pendingin adalah yeast and mold, aerobe bacteria dan Sulphate Reduction Bacteria (SRB). Tetapi pertumbuhannya ditekan dengan adanya penambahan biocide. Secara kuantitatif didapat bahwa total pertumbuhan yeast and mold menurun dari $10^{7} \mathrm{cfu} / \mathrm{ml}$ menjadi $10^{3} \mathrm{cfu} / \mathrm{ml}$. SRB dan aerobe bacteria menjadi tidak terdeteksi. Dari hasil percobaan ini dapat disimpulkan bahwa sistim pengelolaan air pendingin sekunder RSG GAS adalah sangat baik didalam menekan pertumbuhan mikroba. Dari sisi korosi baja karbon pipa pendingan sekunder, masih harus dilakukan penelitian lanjutan hingga dapat menentukan struktur perubahan baja karbon secara mikro.
\end{abstract}

Kata kunci: surveillance, korosi, bakteri,

\section{ABSTRACT}

SURVEILLANCE MANAGEMENT FOR SECONDARY WATER COOLING QUALITY OF RSG GAS. The experiment on surveillance corrosion of carbon steel which come from RSG GAS secondary cooling pipe and identification of microbe exist has been done. The main objective is to understand the effectiveness of the secondary cooling water management RSG GAS with the addition of inhibitors with specific trademark and biocide. The method used is applying a corrosion surveillance and identification of microbial growth. Corrosion surveillance is done by creating a corrosion coupons made of carbon steel of RSG GAS secondary cooling pipe in the shape of disc and assembled in a series, then immersing in tap water storage ponds and a secondary cooling water tower. The evaluation of the results is done visually after immersion for four months. Identification of microbial growth is done by using a very simple tool kit that only need few seconds dipping into the water samples, wait for 24 to 36 hours, and then compare it to a reference manufacturer to determine the range of the number of existing colonies per $\mathrm{ml}$ sample. From the experimental results is understood that the products of 
corrosion of carbon steel cooling pipes secondary is more suppressed due to the addition of inhibitors. The microbes that were detected in the cooling tower basin are yeast and mold, aerobe bacteria and Sulfate Reduction Bacteria (SRB). However, their growth is suppressed by the addition of biocide. Quantitatively, the total yeast and mold growth decreased from $10^{7}$ $\mathrm{cfu} / \mathrm{ml}$ to $10^{3} \mathrm{cfu} / \mathrm{ml}$. SRB and aerobe bacteria is becoming undetected. From this experiment results, it can be concluded that the RSG GAS secondary cooling water management is excellent on suppressing the growth of microbes. However, from the surveillance corrosion of carbon steel secondary cooling pipes is still need further research to understand micro structure changes.

Keywords: surveillance, corrosion, bacteria

\section{INTRODUCTION}

Corrosion is broadly defined as a destruction or deterioration of metal by direct chemical and electro-chemical reaction with its environment. In general, the main factors that affecting the corrosion rate is material dependent or environment-dependent or a combination of both. Some of the factors which associated mainly with metals are chemical and physical homogeneity of the metal surface, $\mathrm{pH}$ solution, temperature, oxygen content, and rate of flow of solution in contact with metal surface $(1,2)$.

On the other hand, the microbiologically induced corrosion (MIC) may have a contribution on causing the metal surfaces damage (3 5). During the colonization of the solid surfaces the population of microorganisms increases rapidly forming a kind of biofilm, which covers the attacked surface. If the microorganisms exist in the aqueous solution, they may first attack to the surface and then grow by forming a cohesive structure known as a biofilm. This process depends on the surface characteristics of substrates, including metal surface free energy, roughness, hydrophobicity, and metallurgical features $(6,7)$. In other words, the bio corrosion is the result of the synergetic interactions of the metal surface, abiotic corrosion products, bacterial cells and cells metabolites (3). The metal surfaces are mostly affected by bacteria existing in land and water as the sulfate-reducing bacteria (SRB), iron oxidizing/reducing bacteria, manganese-oxidizing bacteria, and bacteria that secrete mucus and organic acids. Research has mentioned bacteria species coexist in biofilms forming complex structures on the corrosive metal surfaces (3). In addition, the combination of SRB and iron-oxidizing bacteria produces a higher level of corrosion than the SRB or iron oxidizing bacteria acting separately (8).

In reality, mmost of the deterioration of material in marine environments is crucially dependent on the bio corrosion processes (9).

Corrosion has a close relation with significance economically, socially and otherwise. Therefore, Corrosion management in Research Reactor 30MW GA SIWABESSY (RSG GAS) is the important scope that should be carried out strictly. Beside the statement above, corrosion has a close relation with the material reliability and ageing management of RSG GAS. Finally, the remaining life of 
the whole reactor structure and system is the key point that would be considered for the regulatory for extending the operating license.

RSG GAS is the biggest research reactor with $30 \mathrm{MW}$ power of Indonesia that located in Serpong area and has played in 30 years old. It continues to play a key role in multipurpose domains of research as, fundamental and applied science, industry, human health care and environmental studies, as well as nuclear energy applications and the development of nuclear science and technology related human resources. Since then, to continue its operation, carefully assessment for whole system especially from the structural materials has to be carried out $(1,2)$.

It has 2 circulation cooling system, primary and secondary. In secondary cooling system, carbon steel is used. The previous secondary cooling pipes have been renewed in some parts because of deteorization and corrosion is the main reason. Some studies on carbon steel corrosion has been studied and published elsewhere, included pitting corrosions (10 14), but none related with the RSG GAS secondary cooling water environment. A proper water quality management towards corrosion prevention is needed to maintain the pipes to be utilized for more than 20 years.(15)

The RSG GAS applied the addition of inhibitor with specific company trademark and biocide to suppress the corrosion process and microbial induced corrosion as well. The experiment on surveillance corrosion of carbon steel which come from RSG GAS secondary cooling pipe and identification of microbe exist is need to be done. This paper will describe the effectiveness of the secondary cooling water management. The experimental method used is applying a corrosion surveillance and identification of microbial growth. The material used for corrosion surveillance is carbon steel of RSG GAS secondary cooling pipe. Coupon disc in a serries is made, then immersing in tap water storage ponds and a secondary cooling water tower. Visual evaluation is carried out. Identification of microbial growth is done by using a tool kit. Comparing the experimental results with the company given refferences is done to count the number of colony per mil sample. The chemically content of secondary cooling water is an addition method applied to understand. $\mathrm{pH}$, conductivity and Total dissolved solids are the parameters measured, and $\mathrm{pH}$-meter, conductivitimeter and TDS-meter are the instrument analysis used, respectively.

\section{METHODOLOGY}

2.1. Analytical, monitoring and specification for water cooling system.

The objective of these analyses is to understand the effectivity of current water quality management. The parameter analyzed is reported elsewhere.(15) $\mathrm{pH}$, conductivity and Total dissolved solids are the parameters that are measured by using $\mathrm{pH}$-meter, conductivitimeter and TDS-meter, respectively. All the measurement is done at room temperature.

\subsection{Coupon Racks}

The coupon rack design is written in the previous paper (15). Corrosion coupons are made of carbon steel of RSG GAS 
secondary cooling pipe in the shape of disc and assembled in a series, then immersing in tap water storage ponds and a secondary cooling water tower. The evaluation of the results is done visually after immersion for four months.

\subsection{Bacteria}

The determination of total numbers of microbes was done to understand the effectiveness of adding the biocide towards suppressing microbial induced corrosion. The identification is done by using a tool kit that manufactured by one's company. The four locations for water sample is tap water basin, secondary cooling tower, before Heat exchager and after heat exchanger.
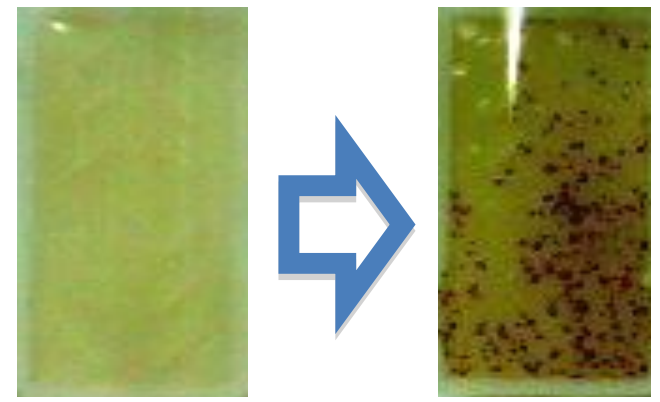

Figure 1.a. Growth of yeast and Mold. Left : blank. Right : The growth in 24 hours incubation

Total number of yeast and mold (Fig.1.a.), was carried out by immersing the paddle into water sample for 2 - 3 seconds so both surfaces are covered with liquid. Drain the excess fluid from paddle by touching the tip to an absorbant of paper. Then, screw back and incubate it in an upright position between 25 and $31{ }^{\circ} \mathrm{C}$ for about 24 - 36 hours. Compare the growth on paddle to the conversion chart available for quantitatively results.
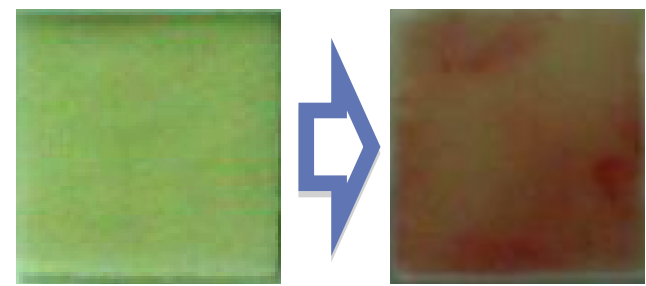

Figure 1.b. Growth of Aerobe Bacteria. Left : blank. Right : The growth in 24 hours incubation

The quailtative aerobe bacteria (Fig.1.b.) is counted by dripping the pad end of strip into the sample for 5 seconds. Then, remove strip from sample, gently shaking excess fluid back into sample container. Open transparent incubation pouch and insert test strip, then sealed top of pouch. Labelling each transparant and incubate between $25-30{ }^{\circ} \mathrm{C}$ for $24-36$ hours. After incubation, compare strip in pouch to interpretation chart available.
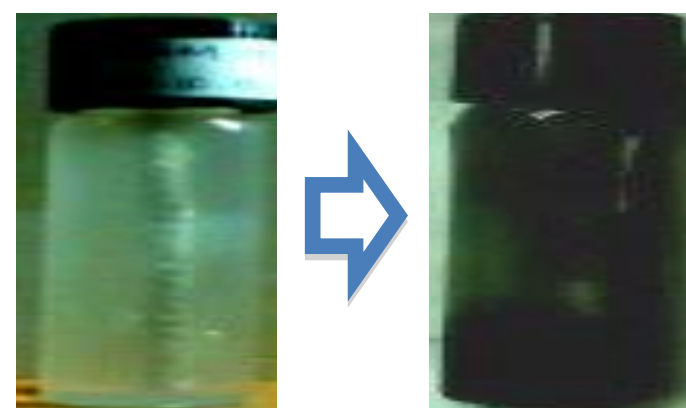

Figure 1.c. Growth of Sulphate Reduction Bacteria (SRB). Left : blank. Right : The growth in 24 hours incubation

The designation Sulphate Reduction Bacteria (SRB) stands for Sulphate Reducing Bacteria, and is shown in Figure 1.c. These are organisms which reduce 
sulphate to sulphide in the absence of oxygen that causes the environment become acid. Low $\mathrm{pH}$ will contribute more $\mathrm{H}^{+}$that initiate a suitable environment for corrosion process. When sulphide is liberated, it reacts with iron in the tubed culture medium to form iron sulphide, a black color growing started from the wick. The degree, to which the medium blackens, along with the length of time it takes to change color, allows for an estimated count of sulphate reducers to be made. Incubate between $25-30{ }^{\circ} \mathrm{C}$ for $24-36$ hours. After incubation, compare the degree to which the medium blackens with the chart available. The completely black color appearance notices the number SRB $>10^{6} \mathrm{cfu} / \mathrm{ml}$, and black color only in a wick notices SRB $>10^{5} \mathrm{cfu} / \mathrm{ml}$. If a black color doesn't appear at the day 5 , it means that SRB $<10$. This bacteria is very potential to reduce sulphate become sulphide

\section{RESULT AND DISCUSSIONS}

\subsection{Corrosion}

The $\mathrm{pH}$, conductivity and TDS for PUSPIPTEK water reservoirs and cooling tower are shown in Table 1

Tap water storage ponds is the raw water coming from PUSPIPTEK, and Cooling Tower water is the water coming from from storage ponds or water coming out from the heat exchanger, where the inhibitor and biocides are added up. Tap water storage ponds is having lower temperature than cooling tower basin, as 28.3 and $33.2{ }^{\circ} \mathrm{C}$, respectively. $\mathrm{pH}$ for cooling tower is higher than from tap water storage pond. It is clear that the inhibitor and biocides causes higher $\mathrm{pH}$, conductivity and TDS for cooling tower water.

Table 1. pH, Conductivity and TDS for secondary cooling water.

\begin{tabular}{ccccc}
\hline & Temp $/{ }^{\circ} \mathrm{C}$ & $\mathrm{pH}$ & Conductivity/ uS/cm & TDS/ppm \\
\hline Tap water & $28.3 \pm 0.1$ & $6.5 \pm 0.3$ & $146.2 \pm 0.3$ & $72.7 \pm 0.4$ \\
Cooling Tower water & 33.2 & 8.1 & 945 & 473 \\
\hline
\end{tabular}

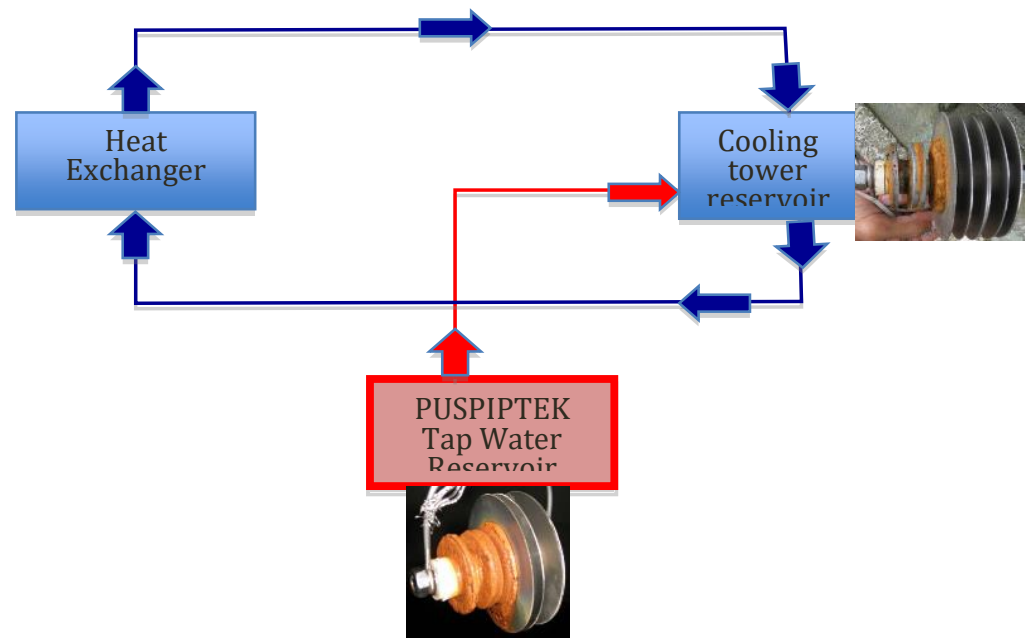

Figure 2. Carbon steel Coupon rack, after immersing for 4 months in tap water reservoir (a) and cooling tower water reservoir (b) 
Conductivity is the ability of aqueous solution to carry an electrical current. The higher value of conductivity shows the higher concentration of ions exist, the higher ability to carry the electrical current, which tend to promote corrosion.

The experimental result for coupons is shown in Figure 2. The orange reddish precipitation formed on the surface coupon immersed in tap water basin is brightly orange and thicker than the one immersed in cooling tower. It is understood that the inhibitor and biocide give a significant effect, less corrosion products appears. The more solid and hard corrosion products covered the coupon immedsed in cooling water tower.

Both stay alone and coupled coupon carbon steel gives different products, which indicates that crevice and galvanic couple has to be considered in design. Based on the results, it is suggested that periodic non destructive inspection for the secondary pipe lines has to be done for understanding the reliability of the cooling pipes. The water circulation should be applied in the cooling tower water basin to minimize contact duration between water and material that may accelerate corrosion.

The carbon steel used in this experiment is taken from stock pipes for secondary cooling system. From the chemical composition analyses (16), it is clear that this is a low carbon steel that is also known as mild steel. It is a low-cost material that is easy to shape. While not as hard as higher-carbon steels, carburizing can increase its surface hardness.

The effect of inhibitor concentration toward corrosion rate of carbon steel at room 44 temperature in detail is described at separate paper which is under submission.(16) The corrosion rate of carbon steel under tap water environment is determined to be approx. $0.2 \sim 0.25 \mathrm{mils} / \mathrm{yr}$, and after being added the inhibitor of $60-100$ ppm, becomes $0.14 \sim 0.16 \mathrm{mils} / \mathrm{yr}$. The optimum inhibition efficiency is approx. $66 \%$. (16) The visual effect for both corrosion rates can be seen at Fig. 2.a and $b$, respectively. The addition of biocide at the same time may give significant effect on inhibition efficiency and need to be clarified in the future work.

One thing that should be taken is the real corrosion rate in the cooling tower water basin should be a bit different than that value, because there are other chemicals added, anti-scale and microbe and also water circulation applied. From this fact, it is predicted that the corrosion rate must be lower than the value obtained in the experimental laboratory and following experiment for obtaining that corrosion rate should be done in the future. The increasing temperature in the cooling tower which not more than $10^{\circ} \mathrm{C}$. Based on this fact, it can be understood that water at cooling tower basin may not give a significant effect on corrosion rate difference, even with the activation energy of $3.5 \mathrm{kCal}$.

\subsection{Microbe}

The map of total existing yeast and mold in the whole secondary cooling water system is shown in Figure 3. Almost no bacteria detected in the tap raw water storage pond. 


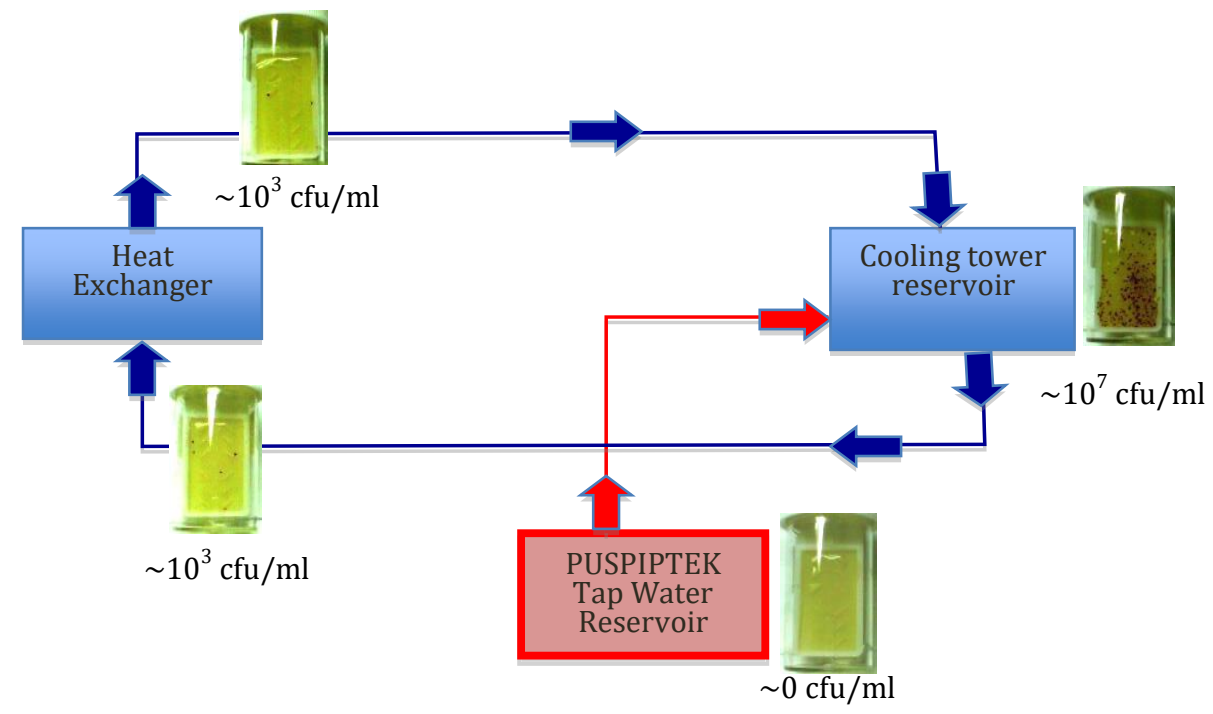

Figure. 3. The growth map distribution of Yeast and Mold in the whole secondary water cooling system of RSG GAS.

However, $10^{7} \mathrm{cfu} / \mathrm{ml}$ is determined in the water cooling tower at the condition of not operated and without any chemicals addition. This is because of the sun shine and water temperature that around $30-35^{\circ} \mathrm{C}$ which let bacteria grow freely in the cooling tower. Since the biocide with concentration of $60 \sim 100 \mathrm{ppm}$, the total bacteria becomes $\sim 10^{3} \mathrm{cfu} / \mathrm{ml}$, and it is the result from the sample taken before entering inlet heat exchanger. The addition of biocide into the secondary water coolant is very effective to suppress the growth of yeast and mold. The efficiency is $99.99 \%$, which is almost $100 \%$. The similar numbers of $10^{3} \mathrm{cfu} / \mathrm{ml}$ found from the water sample taken at the position located after the outlet heat exchanger. It means that the temperature change is neglect able.

More than one sample has been taken from the water cooling tower. It shows some discrepancies. It can be concluded that the homogeneity of anti bacteria chemicals additionn is difficult to be achieved at a very big volume of water cooling tower. The better water circulation management is suggested to be applied for better homogeneity, especially in shorter time laps after adding the chemicals.

The existence of SRB is detected once in the water cooling tower and at one sampling location only, when the reactor is fully stop operation. But, at different location become undetectable. This also mentions that homogeneity is the main cause.

No SRB and aerobe bacteria found on every sampling lines after biocides addition. Based on this experiment, it can be concluded that RSG GAS secondary cooling water management is excellent on suppressing the growth of microbes.

\section{CONCLUSION}

It can be colcluded that the RSG GAS secondary cooling water management is excellent on suppressing the growth of 
microbes. The addition of inhibitor is effective to suppress the corrosion process, but the further work for understanding the micro structure changes of carbon steel secondary pipe is needed and planned to be done in the near future.

\section{ACKNOELEDGMENT}

High akcnowledgement to PTKRN BATAN for supporting this experiment, and also director of RSG GAS who give permission for doing this experiment. Many thanks to colleagues who helped this experiment.

\section{REFFERENCE}

1. IAEA TECDOC 927, 'Influence of Water Chemistry on Fuel Cladding Behavior', 1997.

2. IAEA, TRS 418, 'Corrosion of Research Reactor Aluminum Clad Spent Fuel in Water', 2003.

3. Keith A. Lichti, Monika Ko, Lily Wallis. Galvanic corrosion study of carbon steel to arsenic and antimoby couples. Geothermics, International Journal of Geothermal Research and its Applications $2015 ; 58: 15-21$

4. Enning $D$, Venzlaff $H$, Garrelfs J, Dinh HT, Meyer V, Mayrhofer K, Hassel AW, Stratmann M, Widdel F. Marine sulfatereducing bacteria cause serious corrosion of iron under electro conductive biogenic mineral crust. Environ. Microbiol 2012; 14: 1772-1787.

5. Najoua Labjar, Mounim Lebrini, Fouad Bentiss, Nour-Eddine Chihib, Souad El Hajjaji, Charafeddine Jama. Corrosion inhibition of carbon steel and antibacterial properties of aminotris

(methylenephosphonic) acid. Materials

Chemistry and Physics 2010; 119: 330336.

6. Biljana S. Maluckov. Corrosion of Steels Induced by Microorganisms. Metall. Mater. Eng. 2012; 18 (3): 223-231.

7. Srijan Aggarwal, Philip S. Stewart, and Raymond M. Hozalski. Biofilm Cohesive Strength as a Basis for Biofilm Recalcitrance: Are Bacterial Biofilms Overdesigned. Microbiol Insights 2015; 8 (8): 29-32.

8. Xu C, Zhang Y, Cheng G, Zhu W. Materials characterization, An International Journal on Material Structure and Behaviour 2008; 59: 245255.

9. Starosvetsky J, Starosvetsky D, Armon R. Engineering Failure Analysis 2007; 14: 1500-1511.

10. Cuevas Arteaga C, Porcayo Calderón J, Campos Sedano CF, Rodríguez JA. Comparison of Corrosion Resistance of Carbon Steel and Some Stainless Steels Exposed to $\mathrm{LiBr}-\mathrm{H}_{2} \mathrm{O}$ Solution at low Temperatures. Int. J. Electrochem. Sci. 2012; 7: 445 - 470

11.Cheng YF, , Steward FR, "Corrosion of carbon steels in high-temperature water studied by electrochemical techniques", Corrosion Science 2004; 46 (10): 2405 2420, 2004.

12. Osarolube E, Owate IO, and Oforka N C. Corrosion behavior of mild and high carbon steels in various acidic media. Scientific Research and Essay 2008; 3 (6): 224-228. 
13. Raja VS, Bharat S. Padekar. Role of chlorides on pitting and hydrogen embrittlement of $\mathrm{Mg}-\mathrm{Mn}$ wrought alloy. Corrosion Science 2013; 75: 176-183.

14.Jyoti Bhandari, Faisal Khan, Rouzbeh Abbassi, Vikram Garaniya, Roberto Ojeda. Modelling of pitting corrosion in marine offshore steel structures-A technical review. Journal of Loss Prevention in the Process Industries 2015; 37: 39-62.

15.Geni Rina Sunaryo, Sriyono, Diyah Erlina Lestari. Water Chemistry Surveillance for Multi Purpose Reactor 30 MW GA
Siwabessy, Indonesia - S56/PO.

Proceeding of International Conference

on Research Reactors: Safe

Management and Effective Utilization S56/PO held in Sydney Australia 2007

Nov 5-9. Available from wwwpub.iaea.org/MTCD/Publications/ PDF/P1360_ICRR_2007_CD/datasets/G.

R.\%20Sunaryo.html

16.Geni Rina Sunaryo. Water Chemistry Management toward Corrosion Cooling Piping of Multi Purpose Reactor GA Siwabessy Indonesia. (Under submission, 2017). 
Jurnal Sains dan Teknologi Nuklir Indonesia

ISSN $1411-3481$

Indonesian Journal of Nuclear Science and Technology

EISSN $2503-1287$

Vol. 18, No 1, Februari 2017; 39 - 48 